\title{
Autotrophic denitrification of synthetic nitrate-contaminated groundwater in up-flow fixed-bed bioreactor by pumice as porous media
}

\author{
Masoud Tourang ${ }^{1}$, Behnoush Aminzadeh $^{1 *}$, Ali Torabian $^{1}$ \\ ${ }^{1}$ Department of Environmental Engineering, Graduate Faculty of Environment, University of Tehran, Iran
}

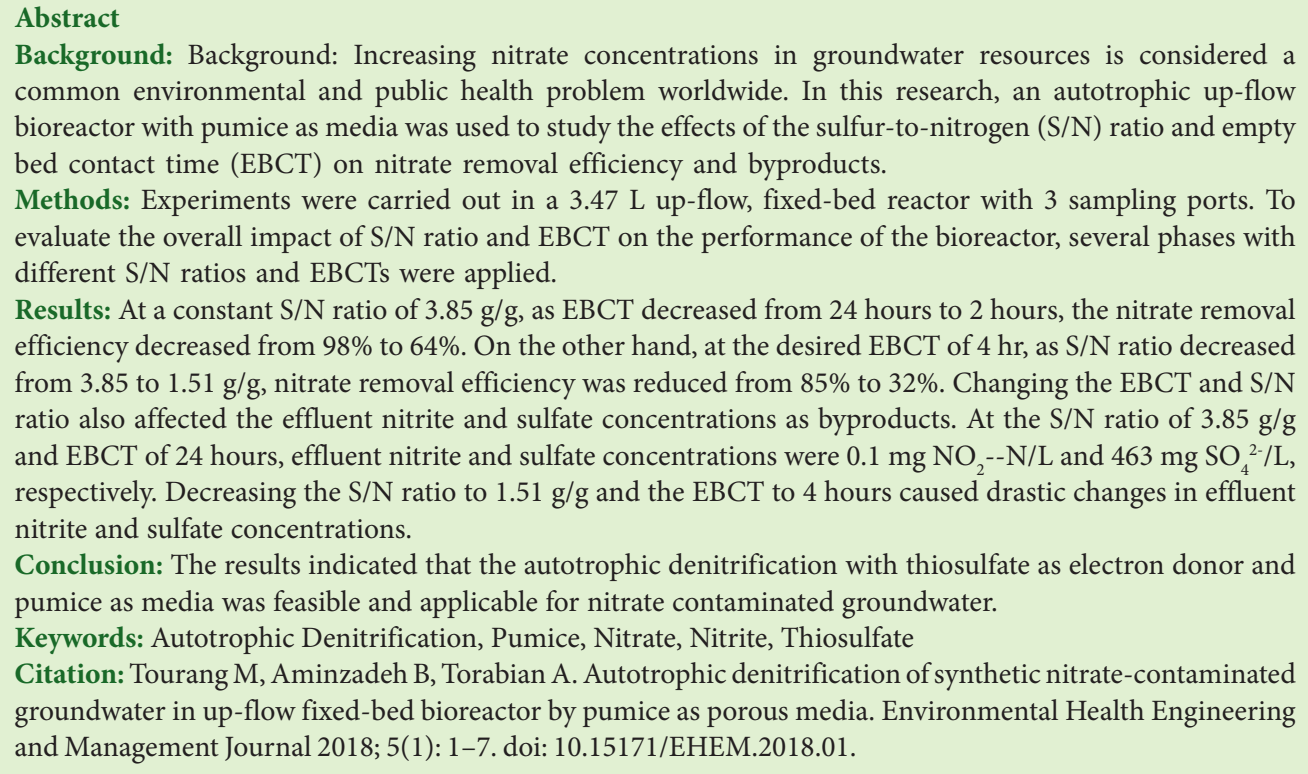

\section{Article History:}

Received: 17 December 2016 Accepted: 5 November 2017 ePublished: 28 February 2018 *Correspondence to:
Behnoush Aminzadeh
Email: bamin@ut.ac.ir

\section{Introduction}

Inorganic nitrogen compounds, such as nitrite, nitrate, and ammonium, are abundant contaminants in ground and surface water. High $\mathrm{NO}_{3}-\mathrm{N}$ concentrations $(>10$ $\mathrm{mg} / \mathrm{L}$ ) have been recorded in numerous aquifers in many countries (1). Nitrate that is used mainly in inorganic fertilizers leaks into the aquifer and surface waters $(2,3)$. It has been estimated that more than $70 \%$ of all nitrate existing in surface and groundwater comes from fertilizers and other materials used in agricultural activities. However, emissions from septic tanks and seep from sewers, atmospheric deposition, and the usage of sewage sludge as fertilizer can all be effective $(4,5)$. In some cases, high nitrate concentrations are caused by natural sources (6). In rural and urban areas of Iran, the growth in agriculture and industry has led to groundwater nitrate concentrations over the acceptable thresholds (7).
Causing eutrophication, nitrate has adverse effects on water ecosystems (8). According to Sun et al (2) and Migeot et al (9), health implications of nitrate in humans include but are not limited to methemoglobinemia, diminished vitality, low weight in newborns, higher chance of fetal death, and formation of carcinogens in the digestive system. In livestock, nitrate contamination can cause reduced weight gain rates.

Among different physical, chemical, and biological nitrate removal processes, biological denitrification is an efficient microbial process that changes nitrate to $\mathrm{N}_{2}$ under anoxic conditions $(1,10,11)$. In this process, four enzymatic steps produce intermediates such as nitrite $\left(\mathrm{NO}_{2}^{-}\right)$, nitric oxide (NO), and nitrous oxide $\left(\mathrm{N}_{2} \mathrm{O}\right)(12)$. Nitrate can be exploited as a terminal electron acceptor by a variety of heterotrophic and autotrophic bacteria. While the former uses organic matters, the latter relies 
on inorganic compounds such as molecular hydrogen, sulfur, sulfide, thiosulfate, and $\mathrm{Fe}^{++}$as electron donors $(7,13)$. Heterotrophic denitrification has been widely applied to wastewater treatment due to its high efficiency and economical aspects (14), but for natural bodies of water, it needs the organic carbon as the electron donor to reduce nitrate and metabolism of heterotrophs. The most important problem of using this process is the existence of residual organic matter such as methanol, ethanol, or acetic acid that may create several problems in the treated water (15).

Compared with heterotrophic treatment, autotrophic treatment is an attractive alternative because of 2 notable advantages. First, since autotrophic denitrification does not need any external organic carbon such as methanol and ethanol, it is very cost effective with a lower risk of secondary contamination compared to heterotrophic denitrification. Second, autotrophic denitrification has a lower cell yield of autotrophic bacteria and, therefore, less sludge production, which minimizes the handling of sludge (16). In autotrophic denitrification, inorganic carbon compounds such as carbon dioxide $\left(\mathrm{CO}_{2}\right)$ and bicarbonate $\left(\mathrm{HCO}_{3}^{-}\right)$are used as carbon sources $(13,17,18)$. The produced $\mathrm{H}^{+}$consumes alkalinity to balance the charge; therefore, some alkaline sources such as limestone are needed to retain the $\mathrm{pH}$ in the best condition for autotrophic denitrifiers $(19,20)$.

In sulfur-based autotrophic denitrification, sulfuroxidizing bacteria such as Thiobacillus denitrificans and Thiomicrospira denitrificans are agents for reducing nitrate to $\mathrm{N}_{2}$ (21-24). A variety of solid materials has been applied as biofilm carriers for attached growth autotrophic denitrification processes like granular-activated carbon $(25,26)$, polystyrene bead (27), elemental sulfur $(28,29)$, zeolite (30), ceramsite (10), and polyurethane foam (31). The aims of this study were to determine the feasibility of using pumice as a biofilm cost-effective carrier, and the effects of S/N ratio, EBCT, and height of bioreactor on nitrate removal efficiency and obtained byproducts.

\section{Methods}

An up-flow bioreactor system, as shown in Figure 1, was used for the experiments. The column bioreactor was made of steel with an inner diameter of $8 \mathrm{~cm}$, height of $80 \mathrm{~cm}$, and total volume of $3.78 \mathrm{~L}$. Three sampling ports were placed at intervals of 23,46, and $69 \mathrm{~cm}$ from the inlet valve. The pumice particles used as biofilm carriers had diameters ranging from $2.36 \mathrm{~mm}$ to $4.75 \mathrm{~mm}$ and a porosity of $60 \%$. Due to the high porosity of pumice, this media has a high specific surface that increases the attached growth. In addition, pumice has some other advantages such as low cost and availability in all parts of Iran. The bioreactor was fed continuously in the up-flow mode using an adjustable peristaltic pump with the minimum flow rate of $0.5 \mathrm{~L} / \mathrm{min}$. Influent groundwater was taken from one of the Tehran's Qanats (Iran). The chemical properties of the

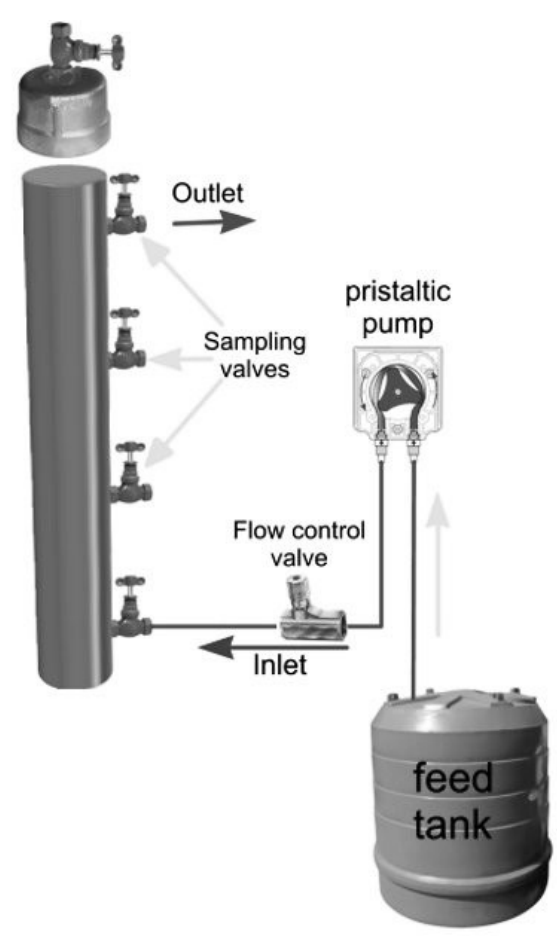

Figure 1. Experimental set-up.

water of the Qanat are shown in Table 1. To achieve the desired influent nitrate concentration (150 mg/L), $\mathrm{KNO}_{3}$ was added to the influent (32).

The inoculum was obtained from the returned anoxic activated sludge of the $\mathrm{A} 2 \mathrm{O}$ process treating municipal wastewater in the Shahrak-e-Ekbatan wastewater treatment plant in Tehran (Iran). To pre-enrichment the autotrophic denitrifying biomass, a synthetic medium consisting of $3.0 \mathrm{~g} \mathrm{KNO}_{3} / \mathrm{L}, 6.0 \mathrm{~g} \mathrm{Na}_{2} \mathrm{~S}_{2} \mathrm{O}_{3} .5 \mathrm{H}_{2} \mathrm{O} / \mathrm{L}, 1.5 \mathrm{~g}$ $\mathrm{NaHCO}_{3} / \mathrm{L}, 0.3 \mathrm{~g} \mathrm{KH}_{2} \mathrm{PO}_{4} / \mathrm{L}, 0.4 \mathrm{~g} \mathrm{MgSO}_{4} .7 \mathrm{H}_{2} \mathrm{O} / \mathrm{L}$, and 1 $\mathrm{ml} / \mathrm{L}$ of trace element containing $5.74 \mathrm{~g} \mathrm{NH}_{4} \mathrm{Cl} / \mathrm{L}, 5.6 \mathrm{~g}$ $\mathrm{K}_{2} \mathrm{HPO}_{4} / \mathrm{L}, 1 \mathrm{~g} \mathrm{MgCl}_{2} / \mathrm{L}, 1 \mathrm{~g} \mathrm{FeCl}_{2} .6 \mathrm{H}_{2} \mathrm{O} / \mathrm{L}, 1 \mathrm{~g} \mathrm{MnSO}_{4}$. $\mathrm{H}_{2} \mathrm{O} / \mathrm{L}$, and $1 \mathrm{~g} \mathrm{CaCl}_{2} / \mathrm{L}$ was added to the inoculum in a master culture reactor. After sufficient bacterial growth, the bioreactor was inoculated with one liter of the culture reactor. The rest of the bioreactor volume was filled with synthetic groundwater. After a few hours, the bioreactor was operated continuously at an empty bed contact time (EBCT) of 24 hours with synthetic groundwater as influent. The autotrophic denitrification process needs an electron donor to participate in the oxidation/reduction mechanism. Sodium thiosulfate was added to the influent as the electron donor. At first, the bioreactor was operated

Table 1. Chemical properties of the water of the Qanat

\begin{tabular}{ll}
\hline Chemical parameter & Concentration $(\mathrm{mg} / \mathrm{L})$ \\
\hline Nitrate $\left(\mathrm{No}_{3}{ }^{-}\right)$ & $11 \pm 1$ \\
Nitrite $\left(\mathrm{No}_{2}{ }^{-}\right)$ & $1.80 \pm 0.15$ \\
Sulfate $\left(\mathrm{So}_{4}^{-2}\right)$ & $110 \pm 13$ \\
Alkalinity (as CaCO3) & $228 \pm 24$ \\
$\mathrm{pH}$ & $7.40 \pm 3$ \\
\hline
\end{tabular}


with the maximum electron donor concentration (500 $\left.\mathrm{mg} / \mathrm{L} \mathrm{Na}_{2} \mathrm{~S}_{2} \mathrm{O}_{3} .5 \mathrm{H}_{2} \mathrm{O}\right)$ and different EBCTs $(2,4,8,16$, and 24 hours). In this step, the desired EBCT was determined. Then, in this desired EBCT, the effects of electron donor concentration and column height on denitrification efficiency were studied. To determine the effect of the $\mathrm{S} / \mathrm{N}$ ratio on the bioreactor performance, different $\mathrm{S} / \mathrm{N}$ ratios $(3.85,3.05,2.29$, and $1.51 \mathrm{~g} / \mathrm{g})$ were tested. All experiments were conducted at $25 \pm 2^{\circ} \mathrm{C}$.

\section{Analysis methods}

All chemical analyses were performed according to the APHA's Standard Methods for Examination of Water and Wastewater (33). Concentrations of nitrate, nitrite, and sulfate were determined using a HACH DR5000 spectrophotometer (USA). Alkalinity was measured by the titration method, and $\mathrm{pH}$ values were monitored using a standard digital $\mathrm{pH}$ meter (691 Metrohm). In each analysis, at least one in 3 samples was duplicated, and the deviation between the two samples was always less than $5 \%$.

\section{Results}

The effects of flow rates on the denitrification of synthetic groundwater was investigated by increasing the flow rate from $3.47 \mathrm{~L} / \mathrm{d}$ to $41.62 \mathrm{~L} / \mathrm{d}$ with a corresponding EBCT of 24 to 2 hours at the $\mathrm{S} / \mathrm{N}$ ratio of $3.85 \mathrm{~g} / \mathrm{g}$. Figure 2 shows the variations of nitrate removal efficiency and effluent nitrate concentration during the operation. The maximum nitrate removal efficiency of $98 \%$ was obtained with an EBCT of 24 hours. As EBCT was decreased from 24 to 2 hours, the nitrate removal efficiency decreased from $98 \%$ to $64 \%$ and the effluent nitrate concentration increased from 3 to $54 \mathrm{mg} / \mathrm{L}$. According to Figure 2, changes in nitrate removal efficiency in different EBCTs are not the same. In lower EBCTs, these changes were severe. However, an increase in the nitrate-nitrogen removal rate was observed during EBCT reduction; the nitrate-nitrogen removal rate increased from $33 \mathrm{mg} / \mathrm{L} / \mathrm{d}$ $\mathrm{NO}_{3}{ }^{-}-\mathrm{N}$ in an EBCT of 24 hours to $260 \mathrm{mg} / \mathrm{L} / \mathrm{d} \mathrm{NO}_{3}{ }^{-} \mathrm{N}$ in an EBCT of 2 hours. In an EBCT of 4 hours, since the effluent nitrate concentration of $23 \mathrm{mg} / \mathrm{L}$ was lesser than

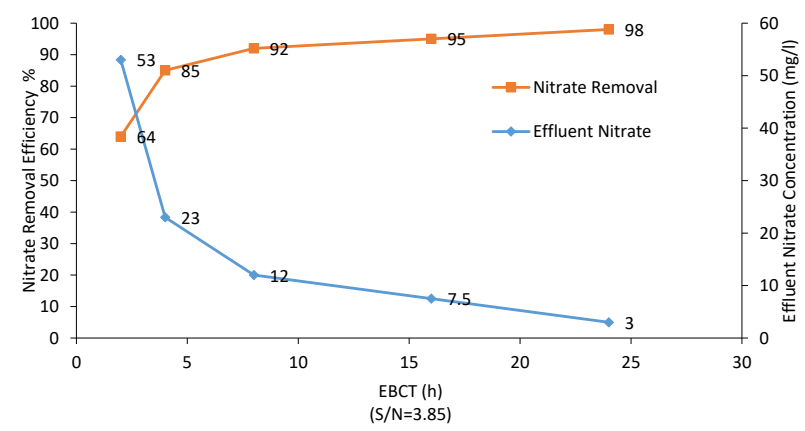

Figure 2. Effects of EBCT on nitrate removal efficiency and effluent nitrate concentration. the regulatory maximum contaminant level of $50 \mathrm{mg} / \mathrm{L}$ for drinking water (according to Iranian standards), this EBCT was selected as the desired EBCT for subsequent experiments (34).

The effects of EBCT on the effluent nitrite and produced sulfate concentrations are shown in Figure 3. Nitrite concentration in the effluent represented the incomplete denitrification.

The optimal range of $\mathrm{pH}$ for autotrophic denitrifiers is 6.8-8.2 (35), and maximum denitrification activity is observed at $\mathrm{pH} 7.5-8.0$ (36). During the experiments, $\mathrm{pH}$ was controlled by adding buffer.

Autotrophic denitrifiers consume alkalinity. According to the current results, the ratio of alkalinity (as $\mathrm{CaCO}_{3}$ ) consumed per $\mathrm{NO}_{3}^{-}-\mathrm{N}$ removed $(\mathrm{g} / \mathrm{g})$ was 2.92 , which was similar to the theoretical ratio (37), and the results found by Chung et al (38) indicated that autotrophic denitrification consumed 3-4 $\mathrm{mg} \mathrm{CaCO}_{3} / \mathrm{mg} \mathrm{NO}_{3}^{-}-\mathrm{N}$.

Effects of $\mathrm{S} / \mathrm{N}$ ratio on nitrate removal and byproducts After determining the EBCT of 4 hours as the desired EBCT, the effect of $\mathrm{S} / \mathrm{N}$ ratio on nitrate removal efficiency was investigated. $\mathrm{S} / \mathrm{N}$ ratios of $3.85,3.05,2.29$, and 1.51 $(\mathrm{g} / \mathrm{g})$ were tested. The stoichiometric $\mathrm{S} / \mathrm{N}$ ratio for complete denitrification is 3.84. Previous studies have shown that in $\mathrm{S} / \mathrm{N}$ ratios between 3.70 and 6.67 , no significant changes in denitrification rate were observed (3).

In Figure 4 the effect of $\mathrm{S} / \mathrm{N}$ ratio on nitrate removal efficiency is shown. At an EBCT of 4 hours, decreasing

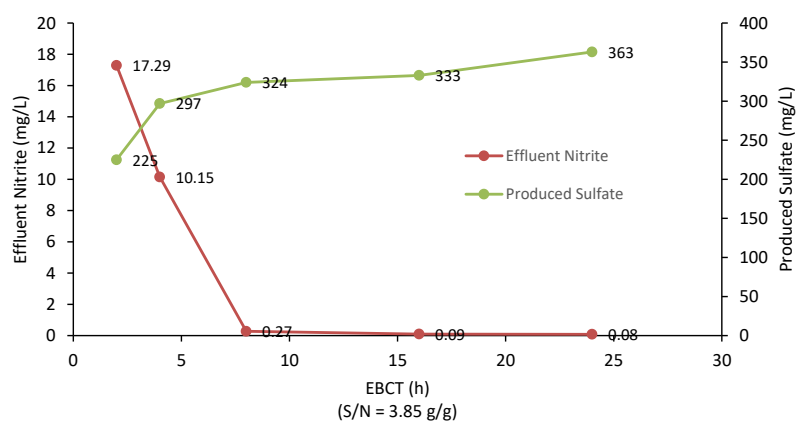

Figure 3. Effects of EBCT on effluent nitrite, and produced sulfate.

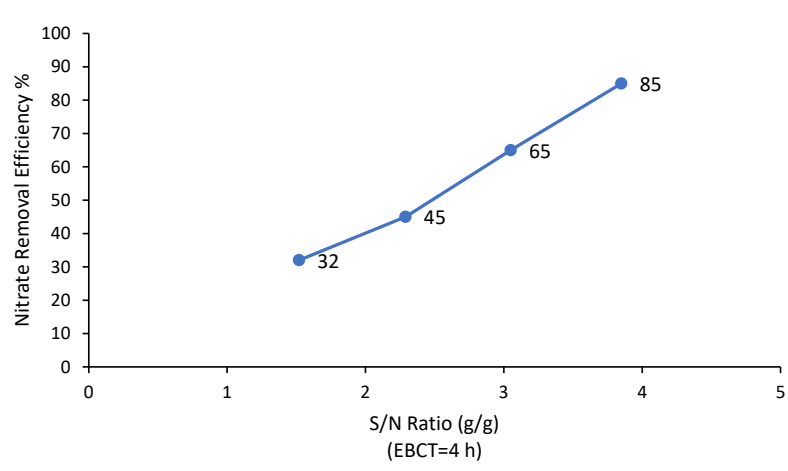

Figure 4. Effect of S/N ratio on nitrate removal efficiency. 
the $\mathrm{S} / \mathrm{N}$ ratio from 3.85 to $1.51(\mathrm{~g} / \mathrm{g})$ reduced nitrate removal efficiency from $85 \%$ to $32 \%$ and increased nitrite accumulation.

Figure 5 illustrates the effect of $\mathrm{S} / \mathrm{N}$ ratio on nitrate, nitrite, and sulfate concentrations. As the $\mathrm{S} / \mathrm{N}$ ratio was reduced, a decrease in the amount of produced sulfate was observed. At the $\mathrm{S} / \mathrm{N}$ ratio of 3.85 , the nitrite concentration in the effluent was $3.95 \mathrm{mg} \mathrm{NO}_{2}^{-} / \mathrm{L}$. By decreasing the $\mathrm{S} / \mathrm{N}$ ratio, nitrite accumulation was increased so that at the $\mathrm{S} / \mathrm{N}$ ratio of 1.51 , about $25 \mathrm{mg} / \mathrm{L}$ nitrite was observed in the effluent. Figures 6,7 and 8 show the profile of effluent nitrate and nitrite concentrations and sulfate production versus reactor height $(23,46$, and $69 \mathrm{~cm})$, at different EBCTs and an $\mathrm{S} / \mathrm{N}$ ratio of $3.85 \mathrm{~g} / \mathrm{g}$, respectively. High rates of nitrate removal and sulfate production at the lower sampling port $(23 \mathrm{~cm})$ were observed in all cases. Generally, the 46 $\mathrm{cm}$ and $69 \mathrm{~cm}$ sampling ports were associated with lower removal and production rates. Increased cell growth at the

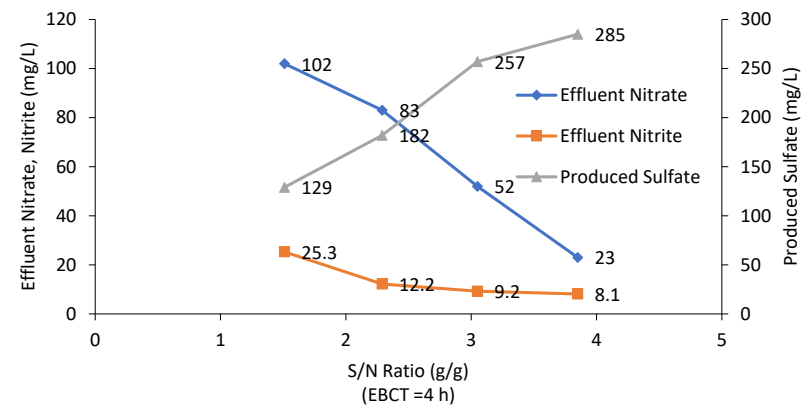

Figure 5. Effects of S/N ratio on effluent nitrate, nitrite, and produced sulfate concentrations.

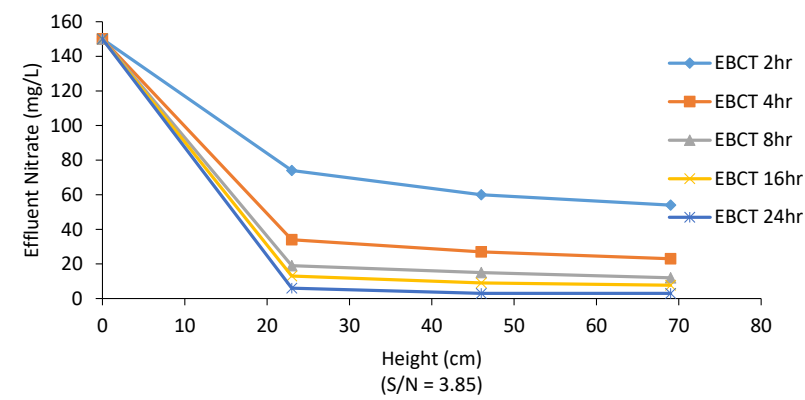

Figure 6. Effects of height and EBCT on effluent nitrate concentration.

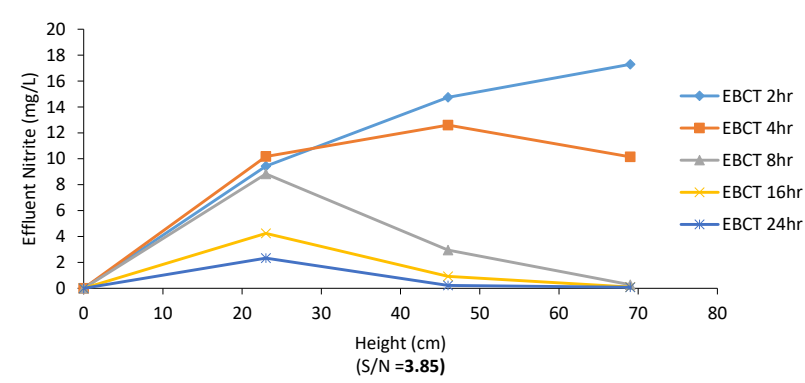

Figure 7. Effects of height and EBCT on effluent nitrite concentration. lower sampling port was anticipated considering the high nitrate and thiosulfate concentration in the feed.

It was observed that at an EBCT of 4 hours, more than $90 \%$ of nitrate removal efficiency occurred in the first 23 $\mathrm{cm}$ of the column. The reduction of EBCT increased the effect of higher parts on the removal of nitrate removal, so that at an EBCT of 2 hours, $50 \%$ of total nitrate removal occurred in the mentioned part of the column (Figure 6). As shown in Figure 7, a rapid accumulation of nitrite was observed in the first $23 \mathrm{~cm}$ of the column at EBCTs of 24, 16 , and 8 hours and an $\mathrm{S} / \mathrm{N}$ ratio of $3.85 \mathrm{~g} / \mathrm{g}$. However, upon completion of denitrification at the height of $46 \mathrm{~cm}$, an intensive nitrite decrease was observed.

Figure 8 shows the effect of column height on effluent sulfate concentration at different EBCTs. The sulfate production profile was very similar to that of nitrate; therefore, a fast increase in sulfate concentration was observed in the first $23 \mathrm{~cm}$ of the column. In upper ports, the increase in sulfate concentration occurred at a slower rate.

\section{Discussion}

Effects of EBCT on nitrate removal and byproducts According to Zhou et al (16), low influent concentration and longer EBCTs improve nitrate removal efficiency. In addition, they reported that the nitrogen in groundwater and effluent from municipal WWT can obtain removal rates of up to $90 \%$ with a four-hour EBCT. However, longer EBCTs are required for water with a nitrate contamination over $70 \mathrm{mg} / \mathrm{L}$. According to this study, reducing the EBCT from 24 hours to 2 hours led to the reduction of nitrate removal efficiency from $98 \%$ to $64 \%$ (with a constant $\mathrm{S} / \mathrm{N}$ ratio of $3.85 \mathrm{~g} / \mathrm{g}$ ).

As shown in Figure 3, at EBCTs of 24, 16, and 8 hours, the effluent nitrite concentrations were less than the maximum allowable level of $3 \mathrm{mg} / \mathrm{L}$. As EBCT decreased to 4 and 2 hours, a drastic nitrite accumulation occurred in the effluent due to incomplete denitrification. Although molecular analysis associates the same microorganisms to denitrifications of nitrate and nitrite into nitrogen (16), the nitrite accumulation in autotrophic denitrification is associated with different causes. High specific utilization rate of nitrate, the reduction in induction time of $\mathrm{NO}_{2}$ reducing enzymes caused by nitrate, the variety in

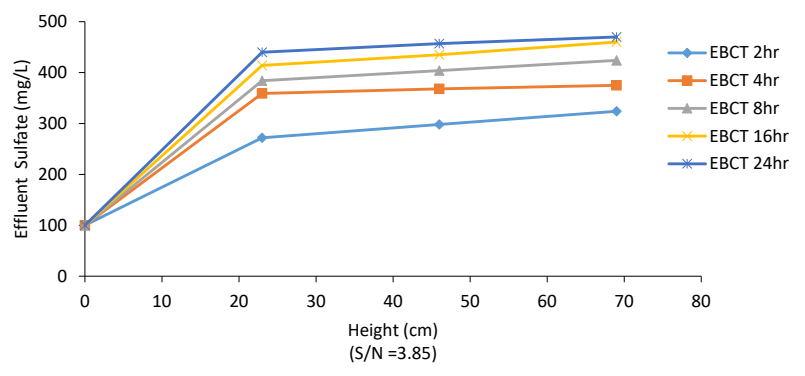

Figure 8. Effects of height and EBCT on effluent sulfate concentration. 
saturation rates and affinities of electron acceptors, and the type of bacteria are all considered to be contributors to nitrate accumulation in this process (39).

When thiosulfate is used as the electron donor, sulfate ion is produced as a byproduct (31). Figure 9 shows the relationship between the produced sulfate and removed nitrate during the steady state condition for the influent $\mathrm{S} / \mathrm{N}$ ratio of $3.85 \mathrm{~g} / \mathrm{g}$ at different EBCTs. It was found that for each $\mathrm{mg} \mathrm{NO}{ }_{3}^{-}$removed, $2.43 \mathrm{mg} / \mathrm{L} \mathrm{SO}_{4}{ }^{2-}$ was produced, which corresponds closely with the stoichiometric ratios of 2.62 and 2.24 derived from Equations (1) and (2), respectively $(37,40)$. The difference between these values is caused by several factors such as feed composition, microbial population, pure culture, temperature, $\mathrm{pH}$, etc.

$0.844 \mathrm{~S}_{2} \mathrm{O}_{3}{ }^{2-}+\mathrm{NO}_{3}{ }^{-}+0.434 \mathrm{H}_{2} \mathrm{O}+0.347 \mathrm{CO}_{2}+0.0865 \mathrm{HCO}_{3}{ }^{-}+$ $0.0865 \mathrm{NH}_{4}^{+} \rightarrow 0.0865 \mathrm{C}_{2} \mathrm{H}_{5} \mathrm{NO}_{2}+0.5 \mathrm{~N}_{2}+1.689 \mathrm{SO}_{4}^{2-}+0.697$ $\mathrm{H}^{+}$

$\mathrm{NO}_{3}{ }^{-}+0.844 \mathrm{~S}_{2} \mathrm{O}_{3}{ }^{2-}+0.347 \mathrm{CO}_{2}+0.0865 \mathrm{HCO}_{3}{ }^{-}+0.0865 \mathrm{NH}$ $4^{+} \rightarrow 0.036 \mathrm{C}_{5} \mathrm{H}_{7} \mathrm{O}_{2} \mathrm{~N}+0.48 \mathrm{~N}_{2}+1.45 \mathrm{SO}_{4}^{2-}+0.045 \mathrm{H}^{+}$

As shown in Figure 9, the produced sulfate had a linear relationship with removed nitrate, and the EBCT had no significant effect on the stoichiometric ratio.

Effect of $\mathrm{S} / \mathrm{N}$ ratio on Nitrate removal and byproducts As shown in Figure 4, decreasing the $\mathrm{S} / \mathrm{N}$ ratio to 1.51 caused a notable decrease in the nitrate removal efficiency. This reduction occurred because of the electron donor shortage. In this case, increasing EBCT did not cause any significant changes in the nitrate removal efficiency; so, it seems that the concentration of electron donor is the controller agent. Campos et al (39) showed that when S/N ratio was less than 2.44 , an increase in nitrite concentration occurred during denitrification.

It can be observed from Figure 5 that, in the denitrification process, a rapid initial decrease in thiosulfate concentration resulting in sudden nitrite accumulation occurred (38). In this case (low $\mathrm{S} / \mathrm{N}$ ratio), the electron donor shortage caused incomplete denitrification and led to the ultimate nitrite accumulation. The results of this study correspond with those of previous studies and show that at $\mathrm{S} / \mathrm{N}$ ratios lower than $4.35(\mathrm{~g} / \mathrm{g})$, the accumulation of nitrite is inevitable (39). In this condition, even in greater EBCTs, nitrite accumulation occurred. Also, $2.43 \mathrm{mg}$ of $\mathrm{SO}_{4}{ }^{2-}$ was produced for each milligram of $\mathrm{NO}_{3}^{-}-\mathrm{N}$ removed, and this ratio did not change with different $\mathrm{S} / \mathrm{N}$ ratios.

Campos et al (39) also showed that sulfate concentrations greater than $500 \mathrm{mg} / \mathrm{L}$ induced inhibitory effects on the nitrate removal efficiency. According to their study, autotrophic denitrifying activity was inhibited to $85 \%$ of that in the control test at a concentration of $5000 \mathrm{mg}$ $\mathrm{SO}_{4}^{2}-\mathrm{S} / \mathrm{L}$. Oh et alreported that sulfate inhibition began at concentrations above $2000 \mathrm{mg} \mathrm{SO}_{4}^{2}$-S/L using a mixed culture (41), while Claus and Kutzner found that this

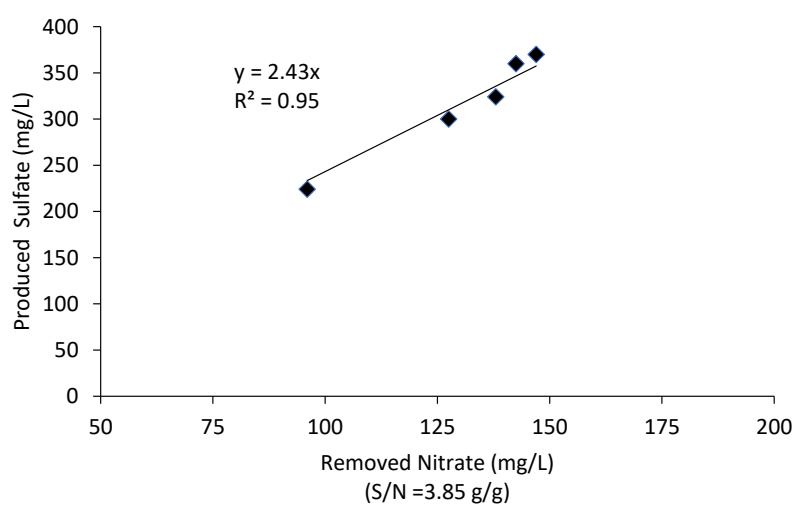

Figure 9. Relationship between removed nitrate and produced sulfate.

compound started to inhibit at $1600 \mathrm{mg} \mathrm{SO}_{4}^{2}$-S/L (36). However, in this study, according to the low concentrations of nitrite and sulfate, the inhibitory effects were negligible.

Effects of column height on nitrate removal and byproducts Moon et al (42) showed that a larger portion of nitrate removal took place in the bottom part of the column. Their findings are very similar to the results of this study that show more than $90 \%$ of nitrate removal occurred in the first $23 \mathrm{~cm}$ of the column (Figure 6). They observed that almost all the nitrate removal occurred in the first $25 \mathrm{~cm}$ of the column, and the effect of $\mathrm{S} / \mathrm{N}$ ratio was negligible. Figure 7 shows the effluent nitrite concentrations at different EBCTs and heights. The results showed a great nitrite accumulation in the first $23 \mathrm{~cm}$, similar to the findings of Moon et al (42) which showed nitrite accumulation at the height of $17 \mathrm{~cm}$. Incomplete denitrification caused primary nitrite accumulation, but in upper heights, nitrite concentration decreased because of complete denitrification. In shorter EBCTs, such as 2 hours and 4 hours, nitrite accumulation continued, so that a great nitrite concentration in the effluent was observed. The behavior of the sulfate concentration was very similar to revers trend nitrate removal (Figure 8). The results showed a notable accumulation of sulfate concentration in the first $23 \mathrm{~cm}$ due to the high rate of nitrate removal in this section of the bioreactor.

\section{Conclusion}

Continuous bioreactor tests showed that pumice granules can be used as neutral media in autotrophic bio-filters and have a significant performance in reducing the nitrate concentration of groundwater. However, parameters such as EBCT, S/N ratio, and column height play important roles in nitrate removal efficiency. While using autotrophic microorganisms for denitrification, byproducts such as nitrite and sulfate (if sulfur-oxidizing bacteria are used) should always be monitored. In fact, parameters that control the efficiency of nitrate removal can also control the byproducts. 


\section{Acknowledgments}

The authors thank the Graduate Faculty of Environment at the University of Tehran for providing laboratory facilities.

\section{Ethical issues}

It is confirmed that this manuscript is the original work of the authors. It has not been published, nor is it under review in another journal, and it is not being submitted for publication elsewhere.

\section{Competing interests}

The authors declare that they have no competing interests.

\section{Authors' contributions}

All authors contributed equally and participated in the collection, analysis, and interpretation of the data. All authors critically reviewed, refined, and approved the manuscript.

\section{References}

1. Huang G, Huang $\mathrm{Y}$, Hu H, Liu F, Zhang Y, Deng R. Remediation of nitrate-nitrogen contaminated groundwater using a pilot-scale two-layer heterotrophicautotrophic denitrification permeable reactive barrier with spongy iron/pine bark. Chemosphere 2015; 130: 8-16. doi: 10.1016/j.chemosphere.2015.02.029.

2. Sun Y, Nemati M. Evaluation of sulfur-based autotrophic denitrification and denitritation for biological removal of nitrate and nitrite from contaminated waters. Bioresour Technol 2012; 114: 207-16. doi: 10.1016/j. biortech.2012.03.061.

3. Fajardo C, Mosquera-Corral A, Campos JL, Méndez R. Autotrophic denitrification with sulphide in a sequencing batch reactor. J Environ Manage 2012; 113: 552-6. doi: 10.1016/j.jenvman.2012.03.018.

4. Rivett MO, Buss SR, Morgan P, Smith JW, Bemment CD. Nitrate attenuation in groundwater: a review of biogeochemical controlling processes. Water Res 2008; 42(16): 4215-32. doi: 10.1016/j.watres.2008.07.020.

5. Breisha GZ, Winter J. Bio-removal of nitrogen from wastewaters - a review. J Am Sci 2010; 6(12): 508-28.

6. Darbi A, Viraraghavan T, Butler R, Corkal D. Pilot-scale evaluation of select nitrate removal technologies. J Environ Sci Health A Tox Hazard Subst Environ Eng 2003; 38(9): 1703-15.

7. Aminzadeh B, Torabian A, Azimi AA, Nabi Bidhendi GR, Mehrdadi N. Salt Inhibition Effects on Simultaneous Heterotrophic/Autotrophic Denitrification of High Nitrate Wastewater. Int J Environ Res 2010; 4(2): 255-62. doi: 10.22059/ijer.2010.17.

8. Wilkinson GM. Eutrophication of Freshwater and Coastal Ecosystems A2 - Abraham, Martin A. Encyclopedia of Sustainable Technologies. Oxford: Elsevier; 2017. p. 145-52. doi: 10.1016/B978-0-12-409548-9.10160-5

9. Migeot V, Albouy-Llaty M, Carles C, Limousi F, Strezlec S, Dupuis A, et al. Drinking-water exposure to a mixture of nitrate and low-dose atrazine metabolites and small-forgestational age (SGA) babies: a historic cohort study. Environ
Res 2013; 122: 58-64. doi: 10.1016/j.envres.2012.12.007.

10. Zhou W, Liu X, Dong X, Wang Z, Yuan Y, Wang H, et al. Sulfur-based autotrophic denitrification from the micropolluted water. J Environ Sci (China) 2016; 44: 180-8. doi: 10.1016/j.jes.2016.01.002.

11. Moraes BS, Souza TS, Foresti E. Characterization and kinetics of sulfide-oxidizing autotrophic denitrification in batch reactors containing suspended and immobilized cells. Water Sci Technol 2011; 64(3): 731-8.

12. Sierra-Alvarez R, Beristain-Cardoso R, Salazar M, Gomez J, Razo-Flores E, Field JA. Chemolithotrophic denitrification with elemental sulfur for groundwater treatment. Water Res 2007; 41(6): 1253-62. doi: 10.1016/j.watres.2006.12.039.

13. Cardoso RB, Sierra-Alvarez R, Rowlette P, Flores ER, Gomez J, Field JA. Sulfide oxidation under chemolithoautotrophic denitrifying conditions. Biotechnol Bioeng 2006; 95(6): 1148-57. doi: 10.1002/bit.21084.

14. Park JY, Yoo YJ. Biological nitrate removal in industrial wastewater treatment: which electron donor we can choose. Appl Microbiol Biotechnol 2009; 82(3): 415-29. doi: 10.1007/s00253-008-1799-1.

15. Wan D, Liu H, Qu J, Lei P, Xiao S, Hou Y. Using the combined bioelectrochemical and sulfur autotrophic denitrification system for groundwater denitrification. Bioresour Technol 2009; 100(1): 142-8. doi: 10.1016/j.biortech.2008.05.042.

16. Zhou W, Sun Y, Wu B, Zhang Y, Huang M, Miyanaga T, et al. Autotrophic denitrification for nitrate and nitrite removal using sulfur-limestone. J Environ Sci (China) 2011; 23(11): 1761-9. doi: 10.1016/S1001-0742(10)60635-3.

17. Zhu I, Getting T. A review of nitrate reduction using inorganic materials. Environ Technol Rev 2012; 1(1): 4658. doi: 10.1080/09593330.2012.706646.

18. Cecconet D, Devecseri M, Callegari A, Capodaglio AG. Effects of process operating conditions on the autotrophic denitrification of nitrate-contaminated groundwater using bioelectrochemical systems. Sci Total Environ 2018; 613614: 663-71. doi: 10.1016/j.scitotenv.2017.09.149.

19. Sahinkaya E, Dursun N. Sulfur-oxidizing autotrophic and mixotrophic denitrification processes for drinking water treatment: elimination of excess sulfate production and alkalinity requirement. Chemosphere 2012; 89(2): 144-9. doi: 10.1016/j.chemosphere.2012.05.029.

20. Park S, Seon J, Byun I, Cho S, Park T, Lee T. Comparison of nitrogen removal and microbial distribution in wastewater treatment process under different electron donor conditions. Bioresour Technol 2010; 101(9): 2988-95. doi: 10.1016/j.biortech.2009.12.012.

21. Shao MF, Zhang T, Fang HH. Sulfur-driven autotrophic denitrification: diversity, biochemistry, and engineering applications. Appl Microbiol Biotechnol 2010; 88(5): 102742. doi: 10.1007/s00253-010-2847-1.

22. Trouve C, Chazal PM, Gueroux B, Sauvaitre N. Denitrification by New Strains of Thiobacillus Denitrificans under Non-Standard Physicochemical Conditions. Effect of Temperature, $\mathrm{pH}$, and Sulphur Source. Environ Technol 1998; 19(6): 601-10. doi: 10.1080/09593331908616716.

23. Trouve C, Ghazal PM. Autotrophic Denitrification by Thiobacillus Denitrificans with Thiosulphate as Sole Energy Source. Pilot Scale Experiments at Low Temperature. Environ Technol 1999; 20(4): 387-95. doi: 


\subsection{0/09593332008616831.}

24. Bruckner CG, Mammitzsch K, Jost G, Wendt J, Labrenz M, Jurgens K. Chemolithoautotrophic denitrification of epsilonproteobacteria in marine pelagic redox gradients. Environ Microbiol 2013; 15(5): 1505-13. doi: 10.1111/j.1462-2920.2012.02880.x.

25. Di Capua F, Milone I, Lakaniemi AM, Hullebusch EDV, Lens PN, Esposito G. Effects of different nickel species on autotrophic denitrification driven by thiosulfate in batch tests and a fluidized-bed reactor. Bioresour Technol 2017; 238: 534-41. doi: 10.1016/j.biortech.2017.04.082.

26. Zou G, Papirio S, Lakaniemi AM, Ahoranta SH, Puhakka JA. High rate autotrophic denitrification in fluidized-bed biofilm reactors. Chem Eng J 2016; 284: 1287-94. doi: 10.1016/j.cej.2015.09.074.

27. Wang Z, Fei X, He S, Huang J, Zhou W. Comparison of heterotrophic and autotrophic denitrification processes for treating nitrate-contaminated surface water. Sci Total Environ 2017; 579: 1706-14. doi: 10.1016/j. scitotenv.2016.11.194.

28. Christianson L, Summerfelt S. Fluidization velocity assessment of commercially available sulfur particles for use in autotrophic denitrification biofilters. Aquacultural Engineering 2014; 60: 1-5. doi: 10.1016/j. aquaeng.2014.03.004.

29. Kostrytsia A, Papirio S, Frunzo L, Mattei MR, Porca E, Collins $\mathrm{G}$, et al. Elemental sulfur-based autotrophic denitrification and denitritation: microbially catalyzed sulfur hydrolysis and nitrogen conversions. J Environ Manage 2018; 211: 313-22. doi: 10.1016/j.jenvman.2018.01.064.

30. Montalvo S, Huilinir C, Galvez D, Roca N, Guerrero L. Autotrophic denitrification with sulfide as electron donor: Effect of zeolite, organic matter and temperature in batch and continuous UASB reactors. Int Biodeterior Biodegradation 2016; 108: 158-65. doi: 10.1016/j.ibiod.2015.12.022.

31. Moraes BS, Souza TS, Foresti E. Effect of sulfide concentration on autotrophic denitrification from nitrate and nitrite in vertical fixed-bed reactors. Process Biochem 2012; 47(9): 1395-401. doi: 10.1016/j.procbio.2012.05.008.

32. Torabian A, Aminzadeh B, Hashemi SH. A study of nitrate in Tehran ground water and a method of its removal. Int J Environ Stud 2000; 57(6): 725-34. doi: 10.1080/00207230008711307.

33. Association, American Water Works Association, Water Environment Federation. Standard Methods for the Examination of Water and Wastewater. Washington DC: APHA, AWWA, WPCF; 2012.

34. Institute of Standards and Industrial Research of Iran. Chemical Specifications of Drinking Water. 5th ed. Tehran: ISIRI; 2009. [Persian].

35. Vidal S, Rocha C, Galvao H. A comparison of organic and inorganic carbon controls over biological denitrification in aquaria. Chemosphere 2002; 48(4): 445-51.

36. Claus G, Kutzner HJ. Autotrophic denitrification by Thiobacillus denitrificans in a packed bed reactor. Appl Microbiol Biotechnol 1985; 22(4): 289-96. doi: 10.1007/ bf00252032.

37. Hashimoto S, Furukawa K, Shioyama M. Autotrophic denitrification using elemental sulfur. J Ferment Technol 1987; 65(6): 683-92. doi: 10.1016/0385-6380(87)90011-2.

38. Chung J, Amin K, Kim S, Yoon S, Kwon K, Bae W. Autotrophic denitrification of nitrate and nitrite using thiosulfate as an electron donor. Water Res 2014; 58: 16978. doi: 10.1016/j.watres.2014.03.071.

39. Campos JL, Carvalho S, Portela R, Mosquera-Corral A, Mendez R. Kinetics of denitrification using sulphur compounds: Effects of $\mathrm{S} / \mathrm{N}$ ratio, endogenous and exogenous compounds. Bioresour Technol 2008; 99(5): 1293-9. doi: 10.1016/j.biortech.2007.02.007.

40. Byun IG, Ko JH, Jung YR, Lee TH, Kim CW, Park TJ. The feasibility of using spent sulfidic caustic as alternative sulfur and alkalinity sources in autotrophic denitrification. Korean J Chem Eng 2005; 22(6): 910-6. doi: 10.1007/bf02705674.

41. Oh SE, Kim KS, Choi HC, Cho J, Kim IS. Kinetics and physiological characteristics of autotrophic dentrification by denitrifying sulfur bacteria. Water Sci Technol 2000; 42(3-4): 59-68.

42. Moon HS, Ahn KH, Lee S, Nam K, Kim JY. Use of autotrophic sulfur-oxidizers to remove nitrate from bank filtrate in a permeable reactive barrier system. Environ Pollut 2004; 129(3): 499-507. doi: 10.1016/j.envpol.2003.11.004. 